\title{
The effects of cadmium chloride on secondary metabolite production in Vitis vinifera cv. cell suspension cultures
}

\author{
Emine Sema Cetin ${ }^{1 *}$, Zehra Babalik², Filiz Hallac-Turk ${ }^{3}$ and Nilgun Gokturk-Baydar ${ }^{4}$
}

\begin{abstract}
Background: Plant secondary metabolites are possess several biological activities such as anti-mutagenic, anti-carcinogenic, anti-aging, etc. Cell suspension culture is one of the most effective systems to produce secondary metabolites. It is possible to increase the phenolic compounds and tocopherols by using cell suspensions. Studies on tocopherols production by cell suspension cultures are seldom and generally focused on seed oil plants. Although fresh grape, grape seed, pomace and grape seed oil had tocopherols, with our best knowledge, there is no research on tocopherol accumulation in the grape cell suspension cultures. In this study, it was aimed to determine the effects of cadmium chloride treatments on secondary metabolite production in cell suspension cultures of grapevine. Cell suspensions initiated from callus belonging to petiole tissue was used as a plant material. Cadmium chloride was applied to cell suspension cultures in different concentration $(1.0 \mathrm{mM}$ and $1.5 \mathrm{mM})$ to enhance secondary metabolite (total phenolics, total flavanols, total flavonols, trans-resveratrol, and $\alpha-, \beta-, \gamma^{-} \delta$-tocopherols) production. Cells were harvested at two days intervals until the $6^{\text {th }}$ day of cultures. Amounts of total phenolics, total flavanols and total flavonols; trans-resveratrol and tocopherols ( $\alpha-, \beta-, \gamma^{-}$and $\delta$-tocopherols) and dry cell weights were determined in the harvested cells.

Results: Phenolic contents were significantly affected by the sampling time and cadmium concentrations. The highest values of total phenolic $(168.82 \mathrm{mg} / 100 \mathrm{~g})$, total flavanol $(15.94 \mathrm{mg} / 100 \mathrm{~g})$, total flavonol $(14.73 \mathrm{mg} / 100 \mathrm{~g})$ and trans-resveratrol $(490.76 \mu \mathrm{g} / 100 \mathrm{~g})$ were found in cells treated with $1.0 \mathrm{mM} \mathrm{CdCl}$ and harvested at day 2. Contents of tocopherols in the cells cultured in the presence of $1.0 \mathrm{mM} \mathrm{CdCl}$ gradually increased during the culture period and the highest values of $\alpha, \beta$ and $\gamma$ tocopherols $(145.61,25.52$ and $18.56 \mu \mathrm{g} / 100 \mathrm{~g})$ were detected in the cell cultures collected at day 6 .
\end{abstract}

Conclusions: As a conclusion, secondary metabolite contents were increased by cadmium chloride application and sampling time, while dry cell weights was reduced by cadmium chloride treatments.

Keywords: Cadmium chloride, Cell, Secondary metabolite

\section{Background}

Plant cell suspension culture is one of the most effective systems to produce secondary metabolites with high amount and purity. Using this system could ensure a continuous supply of uniform quality, specialized, natural components [1,2] compared to traditional extraction methods. Unfortunately, the yield of the desired end-product is often too low to make this a commercially viable alternative to

\footnotetext{
* Correspondence: esemacetin@gmail.com

${ }^{1}$ Department of Horticulture, Faculty of Agriculture and Natural Science, Bozok University, 66200 Yozgat, Turkey

Full list of author information is available at the end of the article
}

extraction from field grown plants. It is possible to increase the secondary metabolite accumulation in the cell culture by using some treatments such as light irradiation, UV, jasmonic acid, ozon, heavy metal, ethylene and sucrose $[3,4]$.

Plant cell culture is considered to be a potential means of producing valuable plant products in a factory setting. Among these products, food additives such as anthocyanins, shikonin compounds, safflower yellow, saffron and colorants are of high interest [5]. With the help of this technique, the presence of anthocyanins and trans-resveratrol were shown in Vitis vinifera suspension culture [6]. 
The phenolic compound family is huge and comprises a complex group of compounds varying from simple phenols to highly polymerised compounds. Polyphenols have been extensively studied and are reported to possess several biological activities. Numerous studies have focused on their anti-mutagenic chemopreventive and anti-carcinogenic activities [7-9].

Resveratrol (3, 4, 5-trihydroxystilbene), a natural polyphenol, is found in some plants that are used in human nutrition. Grape is the major source of resveratrol, and a significant amount can also be found in red wine. Several experimental studies have demonstrated biological properties of resveratrol, especially its anti-inflammatory, antioxidant, anti-platelet and antitumor effects [10]. Many reports have shown that resveratrol can prevent or slow the progression of a wide variety of illnesses, including cancer, cardiovascular disease and ischaemic injuries as well as enhance stress resistance and extend the lifespans of various organisms $[11,12]$. Interest in this compound has been renewed in recent years, first from its identification as a chemopreventive agent for skin cancer, and subsequently from reports that it activates sirtuin deacetylases and extends the lifespans of lower organisms [13].

Tocopherols are another group of secondary metabolites produced in plant cell suspension cultures. Tocopherols as liposoluble, naturally occurring non-polar antioxidants comprising $\alpha$ (5, 7, 8-trimethyltocol), $\beta$ (5, 8-dimethyltocol), $\gamma(7,8$-dimethyltocol) and $\delta$ (8-methyltocol) tocopherols. Tocopherols appear to possess high antioxidant activity by donating the hydrogen of the hydroxyl group to the lipid peroxyl radical [14] and $\alpha$-tocopherol is considered to be extremely important because of its vitamin E activity [15]. Tocopherols are ubiquitous, even if at different concentrations, in oil seeds, leaves and other green parts of higher plants [16].

Studies conducted on the production of tocopherols by cell suspension cultures are seldom and generally focused on seed oil plants [2,17]. Although fresh grape [18], grape seed, pomace [19] and grape seed oil [20-22] had tocopherols in different amounts, with our best knowledge, there is no research on tocopherol accumulation in the grape cell suspension cultures.

Within this study, it was aimed to determine the effects of cadmium chloride $\left(\mathrm{CdCl}_{2}\right)$ treatments on secondary metabolite production in the grape cell suspension cultures to be able to provide a preliminary reference for researchers who study or willing to study on this topic.

\section{Results and discussion}

In the $\mathrm{CdCl}_{2}$ treatments, cell suspension cultures were exposed to increasing concentrations of $\mathrm{CdCl}_{2}$ for up to 6 days. Changes in the dry cell weights were determined as $\mathrm{g} / \mathrm{L}$ and data are showed in Figure 1. Dry cell weights varied depending on the $\mathrm{CdCl}_{2}$ concentrations and

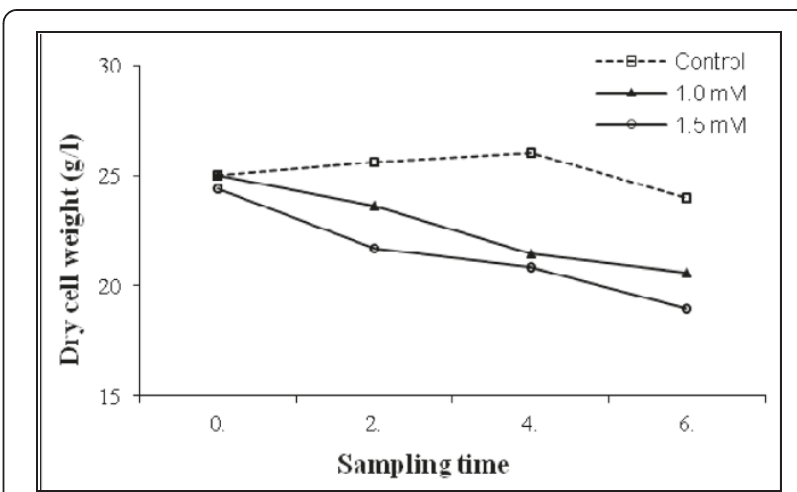

Figure 1 Effects of cadmium chloride on the dry cell weight on cell suspension culture.

sampling time. It was determined that when the $\mathrm{CdCl}_{2}$ concentration increased and the sampling time extended, regular decreases were observed in the dry cell weights. 1.0 and $1.5 \mathrm{mM} \mathrm{CdCl}$ inhibited the growth of cells after 4 days and more dramatically after 6 days.

The data about the effects of cadmium chloride treatments on the phenolic contents of cell suspensions are presented in Table 1. Phenolic contents were significantly affected by the sampling time and cadmium concentrations $(p \leq 0.05)$. The highest values of total phenolic $(168.80 \mathrm{mg} / 100 \mathrm{~g})$, total flavanol $(15.90 \mathrm{mg} / 100 \mathrm{~g})$ and total flavonol $(14.70 \mathrm{mg} / 100 \mathrm{~g})$ were found in cells treated with $1.0 \mathrm{mM} \mathrm{CdCl}_{2}$ and harvested at day 2. Cell suspension cultures treated with $1.5 \mathrm{mM} \mathrm{CdCl}_{2}$ and sampled at days 4 and 6 gave the lowest amounts of total phenolics, total flavanols and total flavonols.

In this study, the production of the trans-resveratrol in the cell cultures was significantly changed depending on the $\mathrm{CdCl}_{2}$ concentrations and sampling time $(p \leq 0.05)$. In the control group, trans-resveratrol showed a gradual increase during the sampling times and the highest value was detected in cell cultures harvested at day 6 . In the cell cultures treated with $1.5 \mathrm{mM} \mathrm{CdCl}_{2}$, trans--resveratrol significantly increased from day 0 to day 4 , but it showed a sharp decrease at day 6 . On the other hand the greatest trans-resveratrol content $(490.76 \mu \mathrm{g} / 100 \mathrm{~g})$ was detected in cell cultures treated with $1.0 \mathrm{mM} \mathrm{CdCl} 2$ and collected at the $2^{\text {nd }}$ day of the application followed by the cells cultured in the media containing $1.0 \mathrm{mM}$ $\mathrm{CdCl}_{2}$ and harvested at day 4 . But it subsequently exhibited a strong decrease in the cells collected at the $6^{\text {th }}$ day of the culture.

Tocopherol composition of the callus samples was affected significantly depending on the $\mathrm{CdCl}_{2}$ concentrations and the sampling times $(\mathrm{P} \leq 0.05)$ as shown in Table 2. The effect was dose-dependent both in terms of time and $\mathrm{CdCl}_{2}$ concentration applied. In terms of tocopherols, $\alpha, \beta$ and $\gamma$-tocopherols were found at different concentrations depending on the treatments, while 
Table 1 The effects of $\mathrm{CdCl}_{2}$ treatments on phenolic contents in Öküzgözü cell suspension cultures

\begin{tabular}{|c|c|c|c|c|c|}
\hline $\mathrm{CdCl}_{2}$ concentrations & Sampling time (day) & Total phenolics $(\mathrm{mg} / 100 \mathrm{~g})$ & $\begin{array}{c}\text { Total flavanols } \\
(\mathrm{mg} / 100 \mathrm{~g})\end{array}$ & $\begin{array}{c}\text { Total flavonols } \\
(\mathrm{mg} / 100 \mathrm{~g})\end{array}$ & $\begin{array}{c}\text { trans-resveratrol } \\
(\mu \mathrm{g} / 100 \mathrm{~g})\end{array}$ \\
\hline \multirow{4}{*}{ Control } & 0. & $102.84 \mathrm{e}^{*}$ & $7.14 d$ & $10.16 \mathrm{bc}$ & $138.12 \mathrm{e}$ \\
\hline & 2. & $128.32 c$ & $5.48 \mathrm{e}$ & $7.78 \mathrm{~d}$ & $139.24 \mathrm{e}$ \\
\hline & 4. & $133.00 \mathrm{c}$ & $7.96 \mathrm{~d}$ & $6.56 \mathrm{~d}$ & $210.65 d$ \\
\hline & 6. & $146.81 b$ & $9.42 \mathrm{C}$ & $6.65 d$ & $216.42 \mathrm{~d}$ \\
\hline \multirow{4}{*}{$1.0 \mathrm{mM}$} & 0. & 100.64 ef & $5.45 \mathrm{e}$ & $10.87 b$ & $251.74 \mathrm{C}$ \\
\hline & 2. & $168.82 \mathrm{a}$ & $15.94 \mathrm{a}$ & $14.73 \mathrm{a}$ & $490.76 \mathrm{a}$ \\
\hline & 4. & $146.24 \mathrm{~b}$ & $12.51 \mathrm{~b}$ & $7.82 \mathrm{~d}$ & $344.62 b$ \\
\hline & 6. & 105.66 de & $9.82 \mathrm{C}$ & $4.54 \mathrm{e}$ & $215.14 d$ \\
\hline \multirow{4}{*}{$1.5 \mathrm{mM}$} & 0. & $112.00 \mathrm{~d}$ & 5.43 e & $9.17 \mathrm{C}$ & $119.46 \mathrm{f}$ \\
\hline & 2. & 108.67 de & $5.85 \mathrm{e}$ & $4.00 \mathrm{e}$ & $137.16 \mathrm{e}$ \\
\hline & 4. & $93.11 \mathrm{f}$ & $3.92 \mathrm{f}$ & $1.86 \mathrm{f}$ & $250.82 \mathrm{c}$ \\
\hline & 6. & $77.27 \mathrm{~g}$ & $4.00 \mathrm{f}$ & $2.23 \mathrm{f}$ & $100.62 \mathrm{f}$ \\
\hline
\end{tabular}

"Differences between means indicated by the same letters are not statistically significant $(p \leq 0.05)$.

$\delta$-tocopherol was not detected in the cell cultures of Öküzgözü. Contents of tocopherols in the cells cultured in the presence of $1.0 \mathrm{mM} \mathrm{CdCl} 2$ gradually increased during the culture period and the highest values of tocopherols were detected in the cell cultures collected at day 6 . The analyses conducted in the present work revealed that these conditions are the most convenient conditions to stimulate the biochemical pathways leading to tocopherols. However, when the $\mathrm{CdCl}_{2}$ concentrations and the culture period increased, tocopherol contents of the cells decreased. Our data indicate that the lowest tocopherol concentrations were found in the cells treated $1.5 \mathrm{mM} \mathrm{CdCl}_{2}$ and sampled after 6 day.

$\mathrm{CdCl}_{2}$ application inhibited the growth of cells. Because it is well known that when cadmium is excess in plants, it inhibits and disturbs various biochemical and physiological processes such as respiration, photosynthesis, cell elongation, plant-water relationships, nitrogen metabolism and mineral nutrition, resulting in poor growth, low biomass, cell death and inhibition of growth [23-25]. Similarly, treatment with $\mathrm{Cd}^{2+}$ at $0.05 \mathrm{mM}$ appeared to inhibit cell division and induce either mitotic or total cell death in the sensitive tobacco cell subpopulation as reported by Kuthanova et al. [26].

Cell suspension cultures treated with $1.5 \mathrm{mM} \mathrm{CdCl}_{2}$ and sampled at days 4 and 6 gave the lowest amounts of total phenolics, total flavanols and total flavonols. These decreases can be resulted from the low cell weight in the presence of high $\mathrm{CdCl}_{2}$ concentrations and long exposure time. Our results confirmed that cytotoxic effects of cadmium in cells were concentration dependent and followed a distinct time course [27]. Similarly, Kuthanova et al. [26] found that treatment with $\mathrm{Cd}^{2+}$ in $1 \mathrm{mM}$ concentration caused total and rapid cell death after $6 \mathrm{~h}$, while

Table 2 The effects of $\mathrm{CdCl}_{2}$ treatments on tocopherol contents in Öküzgözü cell suspension cultures

\begin{tabular}{|c|c|c|c|c|}
\hline $\mathrm{CdCl}_{2}$ concentrations & Sampling time (day) & a- tocopherol $(\mu \mathrm{g} / 100 \mathrm{~g})$ & $\beta$ - tocopherol $(\mu \mathrm{g} / 100 \mathrm{~g})$ & $\gamma$ - tocopherol $(\mu \mathrm{g} / 100 \mathrm{~g})$ \\
\hline \multirow{4}{*}{ Control } & 0. & $118.52 c^{*}$ & $13.53 \mathrm{~d}$ & $6.00 \mathrm{~g}$ \\
\hline & 2. & $83.00 \mathrm{f}$ & $12.50 \mathrm{de}$ & $6.54 \mathrm{fg}$ \\
\hline & 4. & $82.41 \mathrm{f}$ & $17.00 \mathrm{C}$ & $12.46 \mathrm{~b}$ \\
\hline & 6. & $86.12 \mathrm{f}$ & $11.55 \mathrm{e}$ & $11.34 \mathrm{C}$ \\
\hline \multirow{4}{*}{$1.0 \mathrm{mM}$} & 0 & $97.18 \mathrm{e}$ & $11.00 \mathrm{e}$ & $4.00 \mathrm{~h}$ \\
\hline & 2. & $113.00 \mathrm{~cd}$ & $17.12 \mathrm{c}$ & $9.55 \mathrm{e}$ \\
\hline & 4. & $125.54 \mathrm{~b}$ & $17.24 \mathrm{c}$ & $10.53 \mathrm{~cd}$ \\
\hline & 6. & $145.61 \mathrm{a}$ & $25.52 \mathrm{a}$ & $18.56 \mathrm{a}$ \\
\hline \multirow{4}{*}{$1.5 \mathrm{mM}$} & 0. & $102.58 \mathrm{e}$ & $17.00 \mathrm{c}$ & $7.14 \mathrm{f}$ \\
\hline & 2. & $109.55 \mathrm{~d}$ & $21.24 b$ & $11.00 \mathrm{C}$ \\
\hline & 4. & $38.52 \mathrm{~g}$ & $13.35 \mathrm{~d}$ & 10.64 de \\
\hline & 6. & $37.58 \mathrm{~g}$ & $5.57 f$ & $2.20 i$ \\
\hline
\end{tabular}

"Differences between means indicated by the same letters are not statistically significant $(p \leq 0.05)$. 
application of $0.05 \mathrm{mM} \mathrm{Cd}^{2+}$ induced a marked decline of cell viability during the first $24 \mathrm{~h}$ of the cultivation in tobacco cells.

The accumulation of phenolic compounds represents a major key factor in the inducible defense mechanisms of plants through the phenylpropanoid pathway $[28,29]$. The induction of the phenylpropanoid metabolism could also be achieved experimentally by treatments with elicitors or exposure to specific stress conditions [30,31]. With respect to the high abundance of phenolic metabolites in plant tissues, regulation of phenylalanine ammonia lyase activity represents an important step in tolerance to stress factors [32]. Phenolic synthesis is recognized as a result of signalling processes initiated very quickly after injury, an attack of pathogens or elicitation [33,34]. Kuthanova et al. [26] reported that $0.05 \mathrm{mM} \mathrm{Cd}^{2+}$ treated cells correlated with the stimulation of the activity of PAL, key enzyme in phenylpropanoid biosynthesis. They also found that $\mathrm{Cd}^{2+}$ treatment significantly stimulated PAL activity during the whole culture period which was 25 times higher on day 3 when compared to the control cells.

Cadmium is not an essential nutrient for plants and it is normally toxic $[35,36]$. Its toxicity can promote altered metabolism [37] which can include the formation of reactive oxygene species (ROS) in plants under stress situations. Evidence confirmed that $\mathrm{Cd}$ stress induced the production of ROS such as superoxide, hydroxyl radicals $(\mathrm{OH} \cdot)$ and hydrogen peroxide $\left(\mathrm{H}_{2} \mathrm{O}_{2}\right)$ in plants [36]. However the interaction of $\mathrm{Cd}$ and antioxidative systems such as catalase, superoxide dismutase and glutathion reductase only recently have been studied in plant species $[38,39]$. The degree of plant antioxidant enzyme activities under $\mathrm{Cd}$ stress was found in several distinct patterns, which varied according to $\mathrm{Cd}$ concentration, duration, the species and tissues [36]. On the other hand, very little is known about the the responses of grapevine cell cultures in terms of stress defence mechanisms under Cd [40].

\section{Conclusions}

As a conclusion the results of our study showed that $\mathrm{CdCl}_{2}$ treatment can be used for enhancing phenolic compounds and tocopherols in grape cell cultures depending on the $\mathrm{CdCl}_{2}$ concentrations and exposure times. These increases might be explained by hypothesizing that $\mathrm{Cd}$ act as a stres factor on grape cell cultures which stimulate and alter the patways responsible for phenolics and tocopherol biyosynthesis. But high $\mathrm{Cd}$ concentrations and long exposure time had negative effects on cell viability and cell weight. When the treatment is used in high concentrations for long exposure durations, not only the cell division and cell viability but also the secondary metabolite accumulation decreases. To the best of our knowledge, this study reports the use of $\mathrm{CdCl}_{2}$ treatment to enhance phenolics and tocopherols in grape cell suspension culture for the first time. However, further investigations with various strategies for the phenolic and tocopherol contents should also be carried out in grape cell lines.

\section{Methods}

In this research, callus tissues obtained from leaf petioles of Öküzgözü grape cultivar were used. Petioles were surface sterilised with commercial bleach (15\%) for $15 \mathrm{~min}$ and rinsed three times with sterile distilled water. Petioles were then cut into $1 \mathrm{~cm}$ pieces and placed onto a solid B5 [41] culture medium with $30 \mathrm{~g} / \mathrm{L}$ sucrose and 8 $\mathrm{g} / \mathrm{L}$ bacto agar supplemented with $0.5 \mathrm{mg} / \mathrm{L}$ benzylaminopurine (BA), $0.5 \mathrm{mg} / \mathrm{L}$ indole acetic acid (IAA) and 2,4 dichlorophenoxyacetic acid (2,4-D). The $\mathrm{pH}$ was adjusted to 5.75 . Explants were maintained at $25^{\circ} \mathrm{C}$ under dark conditions. Induced calli were subcultured on the same media in order to maintain sufficient stock cultures.

\section{Cell suspension cultures}

Cell suspensions were initiated by inoculating fresh friable fragments of calli ( $2.5 \mathrm{~g}$ each) into $50 \mathrm{~mL}$ of liquid media in $250 \mathrm{~mL}$ Erlenmeyer flasks. Media were supplemented with macro elements (B5 medium), micro elements [42], vitamins [43], $0.1 \mathrm{mg} / \mathrm{L}$ naphtalen acetic acid, $0.2 \mathrm{mg} / \mathrm{L}$ kinetin, $250 \mathrm{mg} / \mathrm{L}$ casein hydrolizate and $20 \mathrm{~g}$ sucrose. Then, they were placed in a rotary shaker $(100 \mathrm{rpm})$. The analyses were replicated three times.

\section{Cadmium chloride $\left(\mathrm{CdCl}_{2}\right)$ treatment}

At day 7, cell cultures were supplied with 1.0 and $1.5 \mathrm{mM}$ $\mathrm{CdCl}_{2}$ dissolved in water. Control treatment did not contain $\mathrm{CdCl}_{2}$. Cells were harvested every $2 \mathrm{~d}$ by filtration, rapidly washed, weighed and stored until day 6 .

\section{Determination of dry cell weight}

Growth kinetics were detrmined by obtaining the dry weight of the cell suspensions as $\mathrm{g} / \mathrm{L}$. Dry cell weights were determined after drying the biomass for 48 hours at $75^{\circ} \mathrm{C}$.

\section{Determination of phenolic compounds}

Phenolic compound extraction were carried out as previously described by Caponio et al. [44]. Total phenolic, total flavanols and total flavonol contents of the samples were determined spectrophotometrically using a PG Instruments T70 Plus Dual Beam Spectrophotometer (Arlington, MA, USA). Total phenolic contents were determined according to the Folin-Ciocalteu colorimetric method [45], calibrating against gallic acid standards and expressing the results as $\mathrm{mg}$ gallic acid equivalents (GAE) $(\mathrm{mg} / 100 \mathrm{~g})$. Total flavanol contents were determined according to the Arnous et al. [46], calibrating against catechin standards and expressing the results as $\mathrm{mg}$ catechin equivalents (CE) (mg/100 g). Total flavonol contents were 
determined according to Dai et al. [47], calibrating against rutin standards and expressing the results as mg rutin equivalents (RE) (mg/100 g). Data presented are average of three measurements.

HPLC analyses were performed on the HPLC system, Shimadzu Corp., Kyoto, Japan. The HPLC system was equipped with a pump (LC $10 \mathrm{AD}$ ), auto-sampler (SIL $10 \mathrm{AD}$ ), column oven (CTO 10A) and diode-array UV/ VIS detector $(\mathrm{DAD}-\lambda \max =278)$. The separation was executed on a Agilent Eclipse XB C-18 $(5 \mu \mathrm{m}, 4.6 \times 250 \mathrm{~mm}$, Wallborn, Germany). The mobile phase was composed of acetic acid (2\%) and methanol with the gradient elution system at a flow rate of $0.8 \mathrm{~mL} / \mathrm{min}$. For gradient elution, mobile phase A contained 3\% acetic acid in water; solvent $B$ contained methanol. The following gradient was used: 0-3 min, from $100 \%$ A to $95 \%$ A, 5\% B; 3-20 min, from $95 \%$ A, $5 \%$ B to $80 \%$ A, $20 \%$ B; $20-30$ min, from $80 \%$ A, $20 \%$ B to $75 \%$ A, $25 \%$ B; 30-40 min, from $75 \%$ A, $25 \%$ B to $70 \% \mathrm{~A}, 30 \% \mathrm{~B} ; 40-50 \min 70 \% \mathrm{~A}, 30 \% \mathrm{~B}$ to $60 \% \mathrm{~A}$, $40 \% \mathrm{~B} ; 50-55 \mathrm{~min}, 60 \% \mathrm{~A}, 40 \% \mathrm{~B}$ to $50 \% \mathrm{~A}, 50 \% \mathrm{~B}$; $55-65 \mathrm{~min}, 50 \% \mathrm{~A}, 50 \% \mathrm{~B}$ to $100 \% \mathrm{~B}$. The injection volume was $20 \mu \mathrm{L}$. Samples, standard solution of transresveratrol and mobile phases were filtered by a $0.45 \mu \mathrm{m}$ pore size membrane filter (Millipore Co. Bedford, MA). The detection UV wavelength was set at $280 \mathrm{~nm}$. The column temperature was set at $30^{\circ} \mathrm{C}$. The compounds were quantified using Shimadzu CLASS-VP software. The contents of trans-resveratrol were determined on HPLC and expressing the results as $\mu \mathrm{g} / 100 \mathrm{~g}$. Data presented are average of three measurements.

\section{Determination of tocopherols}

The extraction of tocopherols $(\alpha, \beta, \gamma$ and $\delta$-tocopherol) were carried out as previously described by Caretto et al. [2]. Briefly, the method consisted of an alkaline hydrolysis (potassium hydroxide 60\%) followed by extraction with $n$ hexane-ethyl acetate (9:1). Chromatography separation was performed by using a Beckman HPLC Analytical System. Luna Silica $(250 \times 4.6 \mathrm{~mm}) 5 \mu$ column was used with heptane/tetrahydrofuran (95:5) as the mobile phase. RF10AXL Floresan dedector was used to determine tocopherols. The tocopherol content was calculated as $\mu \mathrm{g} / 100 \mathrm{~g}$ Fresh Cell Weight (FCW). Each experiment was carried out with at least three replicates.

\section{Statistical analysis}

Data were subjected to analysis of variance with mean separation by Duncan's multiple range test. Differences were considered statistically significant at the $p \leq 0.05$ levels. Statistical analysis was performed using SPSS 16.0 for Windows.

\section{Competing interests}

The authors declare that they have no competing interests.

\section{Authors' contributions}

All authors contributed the manuscript at all stages-eg, literature search, laboratory analysis and interpretation of data, writing etc. All authors read and approved the final manuscript.

\section{Author details}

${ }^{1}$ Department of Horticulture, Faculty of Agriculture and Natural Science, Bozok University, 66200 Yozgat, Turkey. ${ }^{2}$ Fruit Research Station, Republic of Turkey Ministry of Food, Agriculture and Livestock, Egirdir, Isparta, Turkey. ${ }^{3}$ Department of Horticulture, Faculty of Agriculture, Suleyman Demirel University, Isparta, Turkey. ${ }^{4}$ Department of Agricultural Biotechnology, Faculty of Agriculture, Suleyman Demirel University, Isparta, Turkey.

Received: 23 June 2014 Accepted: 16 August 2014

Published: 23 September 2014

\section{References}

1. Dörnenburg $H$, Knorr D: Challenges and opportunities for metabolite production from plant cell and tissue cultures. Food Technol 1997, 51:47-53.

2. Caretto S, Speth B, Fachechi C, Gala R, Zacheo G, Giovinazzo G: Enhancement of vitamin E production in sunflower cell cultures. Plant Cell Rep 2004, 23:174-179.

3. Rakwal R, Tamogami S, Kodama O: Role of jasmonic acid as a signaling molecule in copper chloride elicited rice phytoalexin production. Biosci Biotech Bioch 1996, 60:1046-1048.

4. Qu JG, Zhang W, Jin MF, Yu XJ: Effect of homogeneity on cell growth and anthocyanin biosynthesis in suspension cultures of Vitis vinifera. Chinese J Biotechnol 2006, 22:805-810.

5. Misawa M: Plant tissue culture: an alternative for production of useful metabolites. FAO Agric Serv Bull 1994, 108:89.

6. Waffo Teguo P, Hawthorne ME, Cuendet M, Merillon JM, Kinghorn AD, Pezzuto JM, Mehta RG: Potential cancer-chemopreventive activities of wine stilbenoid and flavans extracted from grape (Vitis vinifera) cell cultures. Nutr Cancer 2001, 40:173-179.

7. Brown JP: A review of the genetic effects of naturally occurring flavonoids, anthraquinones and related compounds. Mutat Res 1980, 75:243-277.

8. Stich HF, Ohshima H, Pignatelli B, Michelon J, Bartsch $\mathrm{H}$ : Inhibitory effect of betel nut extracts on endogenous nitrosation in humans. J Natl Cancer I 1983, 70:1047-1050.

9. Steel VE, Kelloff GJ, Balentine D, Boone CW, Mehta R, Bagheri D, Sigman CC, Zhu S, Sharma SVE: Comparative chemopreventive mechanisms of green tea, black tea and selected polyphenol extracts measured by in vitro bioassays. Carcinogenesis 2000, 21:63-67.

10. Olas B, Wachowicz B, Saluk Juszczak J, Zielinski T: Effect of resveratrol, a natural polyphenolic compound, on platelet activation induced by endotoxin or thrombin. Thromb Res 2002, 107:141-145.

11. Hsieh TC, Wu JM: Resveratrol: Biological and pharmaceutical properties as anticancer molecule. Biofactors 2010, 36:360-369.

12. Wu JM: Resveratrol alleviates some cardiac dysfunction indexes in an SHR model of essential hypertension. Am J Hypertens 2010, 23:115.

13. Baur JA, Sinclair DA: Therapeutic potential of resveratrol: The in vivo evidence. Nat Rev Drug Discov 2006, 5(6):493-506.

14. Tomeo AC, Geller M, Watkins TR: Antioxidant effects of tocotrienols in patients with hyperlipidemia and carotid stress. Lipids 1995, 30:1179-1183.

15. Diplock AT: The role of antioxidant nutritions in disease: Healt and nutrition. Inform 1992, 3:1214-1217.

16. Kamal Eldin A, Appelqvist LA: The chemistry and antioxidant properties of tocopherols and tocotrienols. Lipids 1996, 31:671-701.

17. Fachechi C, Nisi R, Gala R, Leone A, Caretto S: Tocopherol biosynthesis is enhanced in photomixotrophic sunflower cell cultures. Plant Cell Rep 2007, 26:525-530.

18. Göktürk Baydar N: Organic acids, tocopherols and phenolic compositions of some Turkish grape cultivars. Chem Nat Compd 2006, 42:156-159.

19. Göktürk Baydar N, Özkan G: Tocopherol contents of some Turkish wine by-products. Eur Food Res Technol 2001, 223:290-293.

20. Oomah DB, Liang J, Godfrey D, Mazza G: Microwave heating of grape seed: Effect on oil quality. J Agric Food Chem 1998, 46:4017-4021. 
21. Göktürk Baydar N, Akkurt M: Oil content and oil quality properties of some grape seeds. Turk J Agric For 2001, 25:163-168.

22. Gliszcynska Swiglo A, Sikorska E: Simple reversed phase liquid chromatography method for determination of tocopherols in edible plant oils. J Chromatogr A 2004, 1048:195-198.

23. Sanitá-diToppi L, Gabbrielli R: Response to cadmium in higher plants. Environ Exp Bot 1999, 41:105-130.

24. Popova LP, Maslenkova LT, Yordanova RY, Ivanova AP, Krantev AP, Szalai G, Janda T: Exogenous treatment with salicylic acid attenuates cadmium toxicity in pea seedlings. Plant Physiol Bioch 2009, 47:224-231.

25. $\mathrm{Xu} J$, Yin HX, Li X: Protective effects of proline against cadmium toxicity in micropropagated hyperaccumulator, Solanum nigrum L. Plant Cell Rep 2009, 28:325-333.

26. Kuthanova A, Gemperlova L, Zelenkova S, Eder J, Machackovai Opatrny Z, Cvikrova M: Cytological changes and alterations in polyamine contents induced by cadmium in tobacco BY-2 cells. Plant Physiol Biochem 2004, 42:149-156.

27. Fojtova M, Kovarik A: Genotoxic effect of cadmium is associated with apoptotic changes in tobacco cells. Plant Cell Environ 2000, 23(5):531-537.

28. Matern U, Grimmig B: Natural Phenols as Stress Metabolites. Natural Phenols in Plant Resistance. In Acta Hort, Volume 381. Edited by Geibel M, Treutter D, Feucht W. ; 1994:448-462.

29. Dangl JL, Dietrich RA, Thomas H: Senescence and Programmed Cell Death. In Biochemistry and Molecular Biology of Plants. Edited by Buchanan B, Gruissem W, Jones R. Rockville, MD: American Society of Plant Physiologists; 2000:1044-1100.

30. Saltveit ME: Wound induced changes in phenolic metabolism and tissue browning are altered by heat shock. Postharvest Biol Technol 2000, 21:61-69.

31. Cisneros Zevallos $L:$ The use of controlled postharvest abiotic stresses as a tool for enhancing the nutraceutical content and adding-value of fresh fruits and vegetables. J Food Sci 2003, 68:1560-1565.

32. Kacperska A: Water Potential Alteration: A Prerequisite or a Triggering Stimulus for the Development of Freezing Tolerance in Overwintering Herbaceous Plants. In Advances in Plant Cold Hardiness. Edited by Li PH, Christerson L. Boca Raton: CRC Press; 1993:73-91.

33. Bais HP, Walker TS, Schweizer HP, Vivanco JM: Root specific elicitation and antimicrobial activity of rosmarinic acid in hairy root cultures of Ocimum basilicum. Plant Physiol Biochem 2002, 40:983-995.

34. Li W, Koike K, Asada Y, Yoshikawa T, Nikaido T: Rosmarinic acid production by Coleus forskohlii hairy root cultures. Plant Cell Tiss Org 2005, 80:151-155.

35. Leita L, Contin M, Maggioni A: Distribution of Cd and induced Cd-binding proteins in roots, stems and leaves of Phaseolus vulgaris. Plant Sci 1991, 77:139-147.

36. Wang H, Zhao SC, Liu RC, Zhou W, Jin JY: Changes of photosynthetic activities of maize (Zea mays L.) seedlings in response to cadmium stress. Photosynthetica 2009, 47:277-283.

37. Bergmann H, Machelett B, Lippmann B, Friedrich Y: Influnce of heavy metals on the accumulation of trimethylglycine, putrescine and spermine in food plants. Amino Acids 2001, 20:325-329.

38. Ferreira RR, Fornaizer RF, Vitöria AP, Lea PJ, Azevedo RA: Changes in antioxidant enzyme activities in soybean under cadmium stress. J Plant Nutr 2002, 25:327-342.

39. Pereira GJG, Molina SMG, Lea PJ, Azevedo RA: Activity of antioxidant enzymes in response to cadmium in Crotalaria juncea. Plant Soil 2002, 239:123-132.

40. Fornazier RF, Ferreira RR, Pereira GJG, Molina SMG, John Smith R, Lea PJ, Azevedo RA: Cadmium stres in sugar cane callus cultures: Effect on antioxidant ezymes. Plant Cell Tiss Org 2002, 71:25-131.

41. Gamborg OL, Miller RA, Okajima K: Nutrient requirements of suspension cultures of soybean root cells. Exp Cell Res 1968, 50:151-156.

42. Murashige T, Skoog F: A revised medium for rapid growth and bioassays with tobacco tissue cultures. Physiol Plantarum 1962, 15:472-497.

43. Morel G: Le probleme de la transformation tumorale chez les végétaux. Physiol Veg 1970, 8:189-191.

44. Caponio F, Alloggio V, Gomes T: Phenolic compounds of virgin olive oil: Influence of paste preparation techniques. Food Chem 1999, 64:203-209

45. Singleton VL, Rossi JR: Colorimetry of total phenolics with phospho molybdic phosphotungstic acid. Am J Enol Viticult 1965, 16:144-158.
46. Arnous A, Makris DP, Kefalas P: Effect of principal polyphenolic components in relation to antioxidant characteristics of aged red wines. J Agr Food Chem 2001, 49(12):5736-5742.

47. Dai GH, Andary C, Mondolot L, Boubals D: Involment of phenolic compounds in the resistance of grapevine callus to downy mildew (Plasmopara viticola). Eur J Plant Pathol 1995, 101:541-547.

doi:10.1186/0717-6287-47-47

Cite this article as: Cetin et al: The effects of cadmium chloride on secondary metabolite production in Vitis vinifera $\mathrm{cv}$. cell suspension cultures. Biological Research 2014 47:47.

\section{Submit your next manuscript to BioMed Central and take full advantage of:}

- Convenient online submission

- Thorough peer review

- No space constraints or color figure charges

- Immediate publication on acceptance

- Inclusion in PubMed, CAS, Scopus and Google Scholar

- Research which is freely available for redistribution 